\title{
STUDI PENERAPAN KESEHATAN DAN KESELAMATAN KERJA PADA PLTU PUNAGAYA JENEPONTO
}

\author{
Muhammad Yusuf Mappeasse ${ }^{1}$, Indra Wijaya ${ }^{2}$ \\ ${ }^{1}$ Pendidikan Teknik Elektro, Universitas Negeri Makassar \\ muh.yusuf.mappeasse@unm.ac.id \\ ${ }^{2}$ Pendidikan Teknik Elektro, Universitas Negeri Makassar \\ indrawijaya794@gmail.com
}

\begin{abstract}
ABSTRAK
Penelitian ini bertujuan untuk: a) Mengetahui penerapan Kesehatan dan Keselamatan Kerja listrik berdasarkan jenis pekerjaan pada Pembangkit Listrik Tenaga Uap (PLTU ) Punagaya Jeneponto, dan b) Mengetahui penerapan Kesehatan dan Keselamatan Kerja listrik pada lingkungan pekerjaan di PLTU Punagaya Jeneponto berdasarkan standar Permenaker No. 12 Tahun 2015. Subjek pada penelitian ini adalah pekerja pada Pembangkit Listrik Tenaga Uap Punagaya Jeneponto sebanyak 40 orang. Objek pada penelitian ini adalah penerapan kesehatan dan keselamatan kerja listrik pada PLTU Punagaya Jeneponto sesuai jenis pekerjaan dan lingkungan pekerjaan kelistrikan. Teknik pengumpulan data yang digunakan adalah teknik observasi, angket dan dokumentasi. Teknik analisis data yang digunakan adalah teknik analisis deskriptif. Berdasarkan hasil penelitian sebagai berikut; a) Penerapan K3 listrik pada jenis pekerjaan dengan kategori sangat layak dan memenuhi standar Permenaker No. 12 tahun 2015, dan b) Penerapan K3 listrik pada lingkungan pekerjaan dengan kategori sangat layak dan memenuhi standar Permenaker No. 12 tahun 2015.
\end{abstract}

Kata Kunci: Kesehatan dan Keselamatan Kerja, Permenaker No. 12 Tahun 2015.

\section{STUDY ON THE APPLICATION OF OCCUPATIONAL HEALTH AND SAFETY AT PLTU PUNAGAYA JENEPONTO}

\begin{abstract}
This study aims to: a) Knowing the application of Occupational Health and Safety of electricity based on the type of work at the Steam Power Plant (PLTU) Punagaya Jeneponto, and b) Knowing the application of Occupational Health and Safety in the work environment at PLTU Punagaya Jeneponto based on the standards of the Minister of Manpower No. 12 of 2015. The subjects in this study were 40 workers at the Punagaya Jeneponto Steam Power Plant. The object of this research is the application of occupational health and safety in electricity at PLTU Punagaya Jeneponto according to the type of work and the electrical work environment. Data collection techniques used are observation, questionnaires and documentation techniques. The data analysis technique used is descriptive analysis technique. Based on the results of the study as follows; a) The application of electrical $K 3$ to the type of work with a very decent category and meets the standards of the Minister of Manpower No. 12 of 2015, and b) Application of electricity $K 3$ in the work environment with a very decent category and meets the standards of the Minister of Manpower No. 12 of 2015.
\end{abstract}

Keyword: Occupational Health and Safety, Permenaker No. 12 of 2015. 


\section{PENDAHULUAN}

Pelaksanaan keselamatan dan kesehatan kerja (K3) adalah salah satu bentuk upaya untuk menciptakan tempat kerja yang aman, sehat, bebas dari pencemaran lingkungan, sehingga dapat mengurangi dan atau bebas dari kecelakaan kerja dan penyakit akibat kerja yang pada akhirnya dapat meningkatkan efisiensi produktivitas kerja. Kecelakaan kerja dapat menimbulkan korban jiwa maupun kerugian materi bagi pekerja [1].

Berdasarkan [2] tentang keselamatan kerja, kecelakaan kerja adalah suatu kejadian yang tidak diduga semula dan tidak dikehendaki, yang mengacaukan proses yang telah diatur dari suatu aktivitas dan dapat menimbulkan kerugian baik korban manusia maupun harta benda. Pada umumnya kecelakaan kerja disebabkan oleh dua faktor, yaitu manusia dan lingkungan. Faktor manusia yaitu tindakan tidak aman dari manusia seperti sengaja melanggar peraturan keselamatan kerja yang diwajibkan dan kurang terampilnya pekerja itu sendiri, hal ini erat kaitannya dengan jenis pekerjaan yang dilakukan oleh manusia itu sendiri. Sedangkan faktor lingkungan yaitu keadaan tidak aman dari lingkungan kerja yang menyangkut antara lain peralatan atau mesinmesin, tetapi frekuensi terjadinya kecelakaan kerja lebih banyak terjadi karena faktor manusia, karena manusia yang paling banyak berperan dalam menggunakan peralatan di perusahaan.

Menurut [3] yang dihimpun dari sulselsatu.com, salah satu penyebab terjadinya kecelakaan kerja pada pembangkit listrik tenaga uap (PLTU) Punagaya Jeneponto diakibatkan oleh percikan bunga api dari gurinda pekerja yang melakukan pemotongan besi, tiba-tiba tabung gas yang dipakai memotong meledak sehingga terjadi kebakaran yang membakar lahan dan merembes kegudang penampungan solar, oli, tinner, asbes dan lainnya milik PT. China Gezhouba Group Company (CGGC). Dari data kecelakaan tersebut, dapat disimpulkan bahwa kecelakaan kerja berpengaruh pada jenis pekerjaan dan lingkungan pekerjaan.

Melihat potensi kecelakaan yang bisa terjadi dan bahaya yang ditimbulkan oleh pekerjaan khususnya pekerjaan kelistrikan, maka pentingnya sebuah penerapan keselamatan dan kesehatan kerja dalam dunia industri khususnya pada pembangkit listrik yang selalu beroperasi, agar tidak terjadi kecelakaan pada saat bekerja dimana dapat merugikan orang lain dan diri sendiri.

\section{METODE PENELITIAN}

\section{A. Jenis Penelitian}

Penelitian ini merupakan penelitian deskriptif yang bertujuan menggambarkan pelaksanaan penerapan keselamatan dan kesehatan kerja (K3) listrik berdasarkan jenis pekerjaan dan lingkungan pekerjaan pada pembangkit listrik tenaga uap (PLTU) Punagaya Jeneponto.

\section{B. Defenisi Operasional Variabel}

Variabel penelitian menurut [4], adalah segala sesuatu yang berbentuk apa saja yang ditetapkan oleh peneliti untuk dipelajari sehingga diperoleh informasi tentang hal tersebut, kemudian ditarik kesimpulanya. Variabel dalam penelitian ini adalah penerapan K3 listrik pada jenis pekerjaan dan lingkungan pekerjaan pada PLTU Punagaya Jeneponto. Adapun definisi operasional variabel sebagai berikut:

a. Jenis pekerjaan adalah kegiatan yang dilakukan oleh karyawan pada PLTU Punagaya Jeneponto untuk memenuhi kebutuhan perusahaan khususnya pada jenis pekerjaan kelistrikan.

b. Lingkungan pekerjaan adalah segala sesuatu yang ada di sekitar para pekerja PLTU Punagaya Jeneponto yang dapat mempengaruhi pekerja dalam menjalankan tugas-tugas yang dikerjakan khususnya pada lingkungan pekerjaan kelistrikan.

\section{Teknik dan Instrumen Pengumpulan Data}

1. Teknik Pengumpulan Data

Teknik pengumpulan data yang digunakan dalam penelitian ini, sebagai berikut:

\section{a) Observasi}

Observasi merupakan pengumpulan data melalui pengamatan dan pencatatan perilaku subjek penelitian [5]. Penulis melakukan penelitian secara langsung terhadap subjek penelitian untuk memperoleh datadata yang akan digunakan dalam penelitian. Adapun instrumen yang digunakan adalah instrumen observasi dengan penilaian skala Guttman (nilai $1=$ ya, dan $0=$ tidak).

\section{b) Angket}

Angket merupakan teknik pengumpulan data yang dilakukan dengan cara memberi seperangkat pertanyaan atau pernyataan tertulis kepada responden untuk dijawabnya [6]. Salah satu teknik pengumpulan data yang dilakukan oleh peneliti untuk memperoleh informasi tentang penerapan kesehatan dan keselamatan kerja (K3) dengan memberikan angket pada karyawan atau operator yang berada pada PLTU Punagaya Jeneponto. Adapun instrumen yang digunakan adalah instrumen angket dengan penilaian skala Guttman (nilai $1=$ ya, dan $0=$ tidak). 
c) Dokumentasi

Teknik dokumentasi digunakan untuk mengumpulkan data-data yang telah terjadi khususnya pada penerapan kesehatan dan keselamatan kerja (K3) yang bersumber pada dokumentasi yang berada di PLTU Punagaya Jeneponto.

\section{Instrumen Penelitian}

Menurut [7] instrumen penelitian adalah alat atau fasilitas yang digunakan oleh peneliti dalam mengumpulkan data agar pekerjaannya lebih mudah dan hasilnya lebih baik, dalam arti lebih cermat, lengkap, dan sistematis sehingga lebih mudah diolah. Berdasarkan teknik pengumpulan data yang digunakan, maka instrumen penelitian ini menggunakan data observasi, data angket, dan data dokumentasi.

\section{Uji Instrumen Penelitian}

a. Uji Validasi

Validitas adalah suatu ukuran yang menunjukkan tingkat-tingkat kevalidan atau kesahihan suatu instrumen. Sebuah instrumen dikatakan valid apabila mampu mengukur apa yang diinginkan dan dapat mengungkap data dari variabel yang diteliti secara tepat. Tinggi rendahnya validitas instrumen menunjukkan sejauh mana data yang terkumpul tidak menyimpang dari gambaran tentang validitas yang dimaksud [7].

b. Uji Realibilitas

Reliabilitas berasal dari bahasa Inggris reliable yang berarti dapat dipercaya. Reliabilitas instrumen merupakan suatu instrumen dapat dipercaya sesuai dengan kriteria yang telah ditetapkan [7]. Suatu instrumen dapat dikatakan reliable jika selalu memberikan hasil yang sama jika diujikan pada kelompok yang sama pada waktu kesempatan yang berbeda. Metode pengujian reliabilitas instrumen ini menggunakan cara Kuder Richardson-20 (KR-20) [6], dengan rumus sebagai berikut:

$$
r_{11}=\left[\frac{k}{k-1}\right]\left[\frac{S^{2}-\sum p q}{S^{2}}\right]
$$

Keterangan :

$$
\begin{array}{ll}
\mathrm{r}_{11}= & \text { Koefisien reliabilitas internal seluruh } \\
& \text { item } \\
\mathrm{p} & =\text { Proporsi subjek yang menjawab item } \\
& \text { yang benar } \\
\mathrm{q}= & \text { Proporsi subjek yang menjawab item } \\
& \text { yang salah }(\mathrm{q}=1-\mathrm{p}) \\
\sum p q= & \text { Jumlah hasil perkalian antara } \mathrm{p} \text { dan } \mathrm{q} \\
\mathrm{k} & =
\end{array}
$$

$\mathrm{S} \quad=$ Standar deviasi dari test (standar deviasi adalah akar varians)

\section{E. Teknik Analisis Data}

Teknik analisis data adalah suatu cara yang digunakan untuk mengolah data hasil penelitian untuk memperoleh suatu kesimpulan [6]. Dalam penelitian ini teknik analisis data yang digunakan adalah analisis deskriptif untuk menganalisis data dengan cara mendeskripsikan atau menggambarkan sistem penerapan kesehatan dan keselamatan kerja (K3) di PLTU Punagaya Jeneponto.

\section{HASIL DAN PEMBAHASAN}

\section{A. Deskripsi dan Analisis Data}

Untuk mengetahui kelayakan K3, dalam penelitian ini data yang diperoleh dari hasil observasi dan angket mengenai penerapan K3 listrik pada jenis pekerjaan dan lingkungan pekerjaan pada PLTU Punagaya Jeneponto. Data penelitian tersebut meliputi pekerjaan kelistrikan, sarana dan prasanan, rambu-rambu K3 dan SMK3. Penerapan K3 dikatakan layak apabila semua aspek variabel memenuhi standar K3 listrik sesuai Permenaker nomor 12 tahun 2015. Apabila salah satu aspek variabel tidak memenuhi standar tersebut maka dikatakan tidak layak.

1. Jenis Pekerjaan

Berdasarkan hasil pengumpulan data menggunakan instrumen observasi variabel jenis pekerjaan, adapun rangkuman data dapat dilihat pada Tabel 1 sebagai berikut:

TABEL 1. ANALISIS DATA INSTRUMEN OBSERVASI VARIABEL JENIS PEKERJAAN

\begin{tabular}{clcll}
\hline No & $\begin{array}{l}\text { Sub } \\
\text { Variabel }\end{array}$ & $\begin{array}{l}\text { Jumlah } \\
\text { Pertanyaan }\end{array}$ & $\begin{array}{l}\text { Kelayakan } \\
((\%)\end{array}$ & Kategori \\
\hline 1 & $\begin{array}{l}\text { Pekerjaan } \\
\text { Kelistrikan }\end{array}$ & 8 & 100 & $\begin{array}{l}\text { Sangat } \\
\text { Layak }\end{array}$ \\
\hline \multicolumn{2}{c}{ Total } & $\mathbf{8}$ & $\mathbf{1 0 0}$ & $\begin{array}{l}\text { Sangat } \\
\text { Layak }\end{array}$ \\
\hline
\end{tabular}

Berdasarkan hasil analisis data observasi menggunakan rumus persentase diperoleh kesimpulan bahwa pada PLTU Punagaya Jeneponto memiliki kelayakan penerapan K3 listrik pada pekerjaan kelistrikan adalah $100 \%$ dengan kategori sangat layak serta memenuhi standar Permenaker no. 12 tahun 2015.

Berdasarkan hasil pengumpulan data menggunakan instrumen angket variabel jenis pekerjaan, adapun rangkuman data dapat dilihat pada Tabel 2 sebagai berikut: 
TABEL 2. ANALISIS DATA INSTRUMEN ANGKET VARIABEL JENIS PEKERJAAN

\begin{tabular}{|c|c|c|c|c|}
\hline No & Sub Variabel & $\begin{array}{l}\text { Jumlah } \\
\text { Pertanyaan }\end{array}$ & $\begin{array}{l}\text { Kelayakan } \\
(\%)\end{array}$ & Kategori \\
\hline 1 & $\begin{array}{l}\text { Pekerjaan } \\
\text { Kelistrikan }\end{array}$ & 2 & 83,13 & $\begin{array}{l}\text { Sangat } \\
\text { Layak }\end{array}$ \\
\hline \multicolumn{2}{|c|}{ Total } & 2 & 83,13 & $\begin{array}{l}\text { Sangat } \\
\text { Layak }\end{array}$ \\
\hline
\end{tabular}

Berdasarkan hasil analisis data angket menggunakan rumus persentase diperoleh kesimpulan bahwa pada PLTU Punagaya Jeneponto memiliki kelayakan penerapan K3 listrik pada pekerjaan kelistrikan adalah $83,13 \%$ dengan kategori sangat layak, serta memenuhi standar Permenaker No. 12 tahun 2015.

\section{Lingkungan Pekerjaan}

Berdasarkan hasil pengumpulan data menggunakan instrumen observasi variabel lingkungan pekerjaan, adapun rangkuman data dapat dilihat pada Tabel 3 sebagai berikut:

TABEL 3. ANALISIS DATA INSTRUMEN OBSERVASI VARIABEL LINGKUNGAN PEKERJAAN

\begin{tabular}{lllll}
\hline No & $\begin{array}{l}\text { Sub } \\
\text { Variabel }\end{array}$ & $\begin{array}{l}\text { Jumlah } \\
\text { Pertanyaan }\end{array}$ & $\begin{array}{l}\text { Kelayakan } \\
(\%)\end{array}$ & Kategori \\
\hline 1 & $\begin{array}{l}\text { Sarana } \\
\text { dan } \\
\text { Prasarana }\end{array}$ & 24 & 91,67 & $\begin{array}{l}\text { Sangat } \\
\text { Layak }\end{array}$ \\
2 & $\begin{array}{l}\text { Rambu- } \\
\text { Rambu } \\
\text { K3 }\end{array}$ & 5 & 100 & $\begin{array}{l}\text { Sangat } \\
\text { Layak } \\
\text { Sangat }\end{array}$ \\
3 & SMK3 & 3 & 100 & $\begin{array}{l}\text { Sangak } \\
\text { Layak }\end{array}$ \\
\hline Total & $\mathbf{3 2}$ & $\mathbf{9 7 , 2 2}$ & $\begin{array}{l}\text { Sangat } \\
\text { Layak }\end{array}$ \\
\hline
\end{tabular}

Berdasarkan hasil analisis data observasi variabel lingkungan pekerjaan menggunakan rumus persentase diperoleh kesimpulan bahwa pada PLTU Punagaya Jeneponto memiliki kelayakan penerapan K3 listrik 97,22\% dengan kategori sangat layak serta memenuhi standar Permenaker No. 12 tahun 2015. Kelayakan penerapan K3 listrik meliputi, sarana dan prasarana adalah 91,67\% dengan kategori sangat layak, rambu-rambu K3 adalah $100 \%$ dengan kategori sangat layak, dan SMK3 adalah 100\% dengan kategori sangat layak.

Berdasarkan hasil pengumpulan data menggunakan instrumen angket variabel lingkungan pekerjaan, adapun rangkuman data dapat dilihat pada Tabel 4 sebagai berikut:
TABEL 4. ANALISIS DATA INSTRUMEN ANGKET VARIABEL LINGKUNGAN PEKERJAAN

\begin{tabular}{|c|c|c|c|c|}
\hline No & Sub Variabel & $\begin{array}{l}\text { Jumlah } \\
\text { Pertanyaan }\end{array}$ & $\begin{array}{l}\text { Kelayakan } \\
(\%)\end{array}$ & Kategori \\
\hline 1 & $\begin{array}{l}\text { Sarana dan } \\
\text { Prasarana }\end{array}$ & 7 & 95,59 & $\begin{array}{l}\text { Sangat } \\
\text { Layak }\end{array}$ \\
\hline 2 & $\begin{array}{l}\text { Rambu-Rambu } \\
\text { K3 }\end{array}$ & 1 & 93,5 & $\begin{array}{l}\text { Sangat } \\
\text { Layak }\end{array}$ \\
\hline 3 & SMK3 & 6 & 87,75 & $\begin{array}{l}\text { Sangat } \\
\text { Layak }\end{array}$ \\
\hline \multicolumn{2}{|c|}{ Total } & 14 & 92,28 & $\begin{array}{l}\text { Sangat } \\
\text { Layak }\end{array}$ \\
\hline
\end{tabular}

Berdasarkan hasil analisis data angket menggunakan rumus persentase diperoleh kesimpulan bahwa pada PLTU Punagaya Jeneponto memiliki kelayakan penerapan K3 listrik 92,28\% dengan kategori sangat layak serta memenuhi standar Permenaker No. 12 tahun 2015. Kelayakan penerapan K3 listrik meliputi, sarana dan prasarana adalah 95,59\% dengan kategori sangat layak, rambu-rambu $\mathrm{K} 3$ adalah 93,5\% dengan kategori sangat layak, dan SMK3 adalah 87,75\% dengan kategori sangat layak.

Adapun rangkuman hasil keseluruhan observasi dan angket dengan sub variabel pekerjaan kelistrikan, sarana dan prasarana, rambu-rambu K3 dan SMK3 diperoleh data seperti pada Tabel 5 sebagai berikut:

TABEL 5. ANALISIS DATA INSTRUMEN OBSERVASI DAN ANGKET

\begin{tabular}{|c|c|c|c|c|c|}
\hline \multirow{2}{*}{ No } & \multirow{2}{*}{ Sub Variabel } & \multirow{2}{*}{$\begin{array}{l}\text { Jumlah } \\
\text { Pertanyaan }\end{array}$} & \multicolumn{2}{|c|}{ Kelayakan (\%) } & \multirow{2}{*}{ Jumlah } \\
\hline & & & Observasi & Angket & \\
\hline 1 & $\begin{array}{l}\text { Pekerjaan } \\
\text { Kelistrikan }\end{array}$ & 10 & 100 & 83,13 & 91,57 \\
\hline 2 & $\begin{array}{l}\text { Sarana dan } \\
\text { Prasarana }\end{array}$ & 31 & 91,67 & 95,59 & 93,63 \\
\hline 3 & $\begin{array}{l}\text { Rambu- } \\
\text { Rambu K3 }\end{array}$ & 6 & 100 & 93,5 & 96,75 \\
\hline 4 & SMK3 & 9 & 100 & 87,75 & 93,88 \\
\hline \multicolumn{2}{|c|}{ Total } & 56 & 97,92 & 89,99 & 93,96 \\
\hline
\end{tabular}

Berdasarkan hasil analisis data observasi dan angket menggunakan rumus rata-rata diperoleh kesimpulan bahwa pada PLTU Punagaya Jeneponto memiliki kelayakan penerapan K3 listrik 93,96\% dengan kategori sangat layak serta memenuhi standar Permenaker No. 12 tahun 2015. Kelayakan penerapan K3 listrik meliputi, pekerjaan kelistrikan adalah 91,57\% dengan kategori sangat layak, sarana dan prasarana adalah 93,63\% dengan kategori sangat layak, rambu-rambu K3 adalah 96,75\% dengan kategori sangat layak, dan SMK3 adalah 93,88\% dengan kategori sangat layak.

TABEL 6. HASIL KESELURUHAN VARIABEL

\begin{tabular}{lllll}
\hline No & $\begin{array}{l}\text { Sub } \\
\text { Variabel }\end{array}$ & $\begin{array}{l}\text { Jumlah } \\
\text { Pertanyaan }\end{array}$ & $\begin{array}{l}\text { Kelayakan } \\
(\%)\end{array}$ & Kategori \\
\hline 1 & Jenis & 10 & 91,57 & $\begin{array}{l}\text { Sangat } \\
\text { Layak } \\
\text { Pekerjaan }\end{array}$ \\
2 & $\begin{array}{l}\text { Lingkungan } \\
\text { Pekerjaan }\end{array}$ & 46 & 94,75 & $\begin{array}{l}\text { Sangat } \\
\text { Layak }\end{array}$
\end{tabular}




\section{B. Pembahasan}

\section{Jenis Pekerjaan}

Berdasarkan hasil penelitian pada PLTU Punagaya Jeneponto yang diperoleh dari hasil observasi dan angket bahwa jenis pekerjaan kelistrikan terbagi dua yaitu operator dan pemeliharaan, yang memiliki tanggung jawab masing-masing. Pada bagian operator bertanggung jawab penuh dalam pelaksanaan pengoperasian unit-unit pembangkit, sedangkan pada bagian pemeliharaan bertanggung jawab penuh dalam pelaksanaan pemeliharaan unit-unit pembangkit.

Pada dasarnya penerapan K3 listrik dikatakan aman apabila memenuhi standar yang telah ditetapkan oleh Permenaker No. 12 tahun 2015, seperti untuk mencegah terjadinya bahaya listrik dari sentuh langsung, maka bagian aktif harus di isolasi, menutup dengan penghalang atau selungkup, membuat rintangan, memberi jarak aman atau diluar jangkauan dan menggunakan alat pelindung diri saat bekerja. Sedangkan untuk pengendalian listrik dari sentuh tidak langsung seperti menutup semua instalasi yang terbuka, menutup instalasi yang rusak, memperbaiki atau mengganti peralatan yang rusak, menghindari lingkungan kerja yang tidak aman, mengecek atau memeriksa kondisi kawat atau core kabel, menggunakan sistem grounding yang benar, dan menghindari penggunaan yang melebihi kapasitasnya.

Berdasarkan hasil analisis data tentang penerapan K3 listrik pada pekerjaan kelistrikan di PLTU Punagaya Jeneponto diperoleh hasil 91,57\% dengan kriteria sangat layak dan telah memenuhi standar baik dari segi pengaman, penghantar, sambungan hingga perawatan yang dilakukan. Hal ini ditunjukkan pada penghantar aktif diisolasi dengan baik, pemberian penghalang bagi peralatan listrik yang berdaya besar, serta sistem instalasi tenaga yang ada di PLTU Punagaya Jeneponto menggunakan pengaman yang sesuai standar.

\section{Lingkungan Pekerjaan}

Berdasarkan hasil penelitian di PLTU Punagaya Jeneponto dari data observasi dan data angket pada lingkungan pekerjaan diperoleh hasil 94,75\% dengan kriteria sangat layak dan telah memenuhi standar Permenaker No. 12 tahun 2015. Dari segi sarana dan prasarana diperoleh hasil 93,63\% dengan kriteria sangat layak serta memenuhi standar. Hal ini ditinjau dari kondisi lingkungan kerja yang bersih dan nyaman dengan adanya pengatur temperatur pada lingkungan kerja serta peralatan bantu mempercepat sirkulasi udara yang memadai. Adanya alat pengendali kebakaran disetiap ruangan seperti APAR dan hydrant serta penunjang K3 yaitu kotak P3K jika terjadi kecelakaan.

APD yang digunakan para pekerja di PLTU Punagaya Jeneponto telah memenuhi standar kualitas yang baik serta jumlah yang memadai, akan tetapi dibutuhkan penambahan APD, karena mengingat penggunaan APD setiap hari dapat mempercepat kerusakan pada APD. Sehingga dibutuhkan penggantian APD yang sudah tidak layak pakai.

Berdasarkan hasil penelitian mengenai ramburambu K3 yang ada di PLTU Punagaya Jeneponto diperoleh hasil $96,75 \%$ dengan kriteria sangat layak serta memenuhi standar. Hal ini ditinjau dari setiap ruangan dan bagian-bagian lingkungan pekerjaan PLTU Punagaya Jeneponto dilengkapi dengan rambu peringatan, rambu wajib, rambu larangan, rambu pertolongan pertama, dan rambu pemadam api.

Sementara itu, dalam pelaksanaan SMK3 dalam lingkup perusahaan bertujuan untuk menempatkan tenaga kerja sesuai dengan harkat dan martabatnya sebagai manusia, meningkatkan efesiensi dan produktifitas kerja untuk menghadapi kompetisi perdagangan global, meningkatkan komitmen pimpinan perusahaan dalam melindungi tenaga kerja. Dari hasil penelitian mengenai SMK3 telah memenuhi standar dan kriteria sangat layak dengan hasil 93,88\%.

\section{SIMPULAN}

Berdasarkan hasil penelitian tentang studi penerapan kesehatan dan keselamatan kerja di pembangkit listrik tenaga uap (PLTU) Punagaya Jeneponto, maka disimpulkan:

1. Penerapan K3 listrik pada jenis pekerjaan $91,57 \%$ dengan kategori sangat layak sesuai standar Permenaker no. 12 tahun 2015 dan 8,43\% penerapan K3 listrik tidak memenuhi standar.

2. Penerapan K3 listrik pada lingkungan pekerjaan 94,75\% dengan kategori sangat layak (dari segi sarana dan prasarana $93,63 \%$, rambu-rambu K3 96,75\% dan SMK3 93,88\%) serta memenuhi standar Permenaker no. 12 tahun 2015 dan 5,25\% tidak memenuhi standar.

\section{DAFTAR PUSTAKA}

[1] R. D. Wirahadikusumah, "Tantangan Masalah Keselamatan dan Kesehatan Kerja pada Proyek Konstruksi di Indonesia," Fakultas Teknik Sipil dan Lingkungan, Institut Teknologi Bandung (www. ftsl. itb. ac. id/... konstruksi/.../makalahreini-d-wirahadikusumah. pdf, diakses $10 \mathrm{Mei}$ 2010), 2007. 
[2] R. Indonesia and P. R. Indonesia, "Undang Undang No. 1 Tahun 1970 Tentang: Keselamatan Kerja," Sekretariat Negara: Jakarta, 1970.

[3] Dedi, "Kebakaran di PLTU Punagaya Jeneponto, Satu Gudang Terbakar," Sulselsatu.com, Makassar, 14. [Online]. Available:

https://www.sulselsatu.com/2019/09/14/turat ea/kebakaran-di-pltu-punagaya-jenepontosatu-gudang-terbakar.html

[4] Sugiyono, Memahami Penelitian Kuantitatif Kualitatif dan $R \& D$. Bandung: Alfabeta, 2015.

[5] F. Nurmatyas, "Evaluasi Penerapan Kesehatan Dan Keselamatan Kerja (K3) Berdasarkan Sistem Manajement K3 Di Laboratorium Pt. Pebana Adi Sarana Kabupaten Rejang Lebong," STATIKA: Jurnal Teknik Sipil, vol. 6, no. 2, pp. 56-69, 2020.

[6] Sugiyono, Statistika Untuk Penelitian. Bandung: Alfabeta, 2014.

[7] A. Suharsimi, "Prosedur penelitian suatu pendekatan praktik," Jakarta: Rineka Cipta, pp. 120-123, 2006. 